\title{
Impact of $\mathrm{Al}_{2} \mathrm{O}_{3}$ Particle Size on the Open Porosity of $\mathrm{Ni} / \mathrm{Al}_{2} \mathrm{O}_{3}$ Composites Prepared by the Thermal Oxidation at Moderate Temperatures
}

\author{
Andrej Opálek ${ }^{1, *} \mathbb{1}$, Marta Gaburjáková ${ }^{2} \mathbb{D}$, Peter Švec $^{3}$, Stanislav Kúdela, Jr. ${ }^{1}$, Matej Štěpánek ${ }^{1}$, \\ Pavol Štefánik ${ }^{1}$ a and Karol Iždinský ${ }^{1}$ \\ 1 Institute of Materials and Machine Mechanics, Slovak Academy of Sciences, Dúbravská Cesta 9, \\ 84513 Bratislava, Slovakia; stanislav.kudela-ml@savba.sk (S.K.J.); matej.stepanek@savba.sk (M.̌̌.); \\ pavol.stefanik@savba.sk (P.Š.); karol.izdinsky@savba.sk (K.I.) \\ 2 Institute of Molecular Physiology and Genetics, Centre of Biosciences, Slovak Academy of Sciences, \\ Dúbravská cesta 9, 84005 Bratislava, Slovakia; marta.gaburjakova@savba.sk \\ 3 Institute of Physics, Slovak Academy of Sciences, Dúbravská cesta 9, 84511 Bratislava, Slovakia; \\ peter.svec@savba.sk \\ * Correspondence: andrej.opalek@savba.sk
}

\section{check for} updates

Citation: Opálek, A.; Gaburjáková, M.; Švec, P.; Kúdela, S., Jr.; Štěpánek, M.; Štefánik, P.; Iždinský, K. Impact of $\mathrm{Al}_{2} \mathrm{O}_{3}$ Particle Size on the Open Porosity of $\mathrm{Ni} / \mathrm{Al}_{2} \mathrm{O}_{3}$ Composites Prepared by the Thermal Oxidation at Moderate Temperatures. Metals 2021, 11, 1582. https://doi.org/ $10.3390 /$ met11101582

Academic Editor: Evgeny

A. Kolubaev

Received: 20 August 2021

Accepted: 1 October 2021

Published: 4 October 2021

Publisher's Note: MDPI stays neutral with regard to jurisdictional claims in published maps and institutional affiliations.

Copyright: (c) 2021 by the authors. Licensee MDPI, Basel, Switzerland. This article is an open access article distributed under the terms and conditions of the Creative Commons Attribution (CC BY) license (https:/ / creativecommons.org/licenses/by/ $4.0 /)$.
Abstract: The performance of attractive Ni-based composites can be affected by changing their microstructures, e.g., introducing pores. Here, we report a novel, relatively low-cost process to fabricate $\mathrm{Ni} / \mathrm{Al}_{2} \mathrm{O}_{3}$ composites with open porosity modified by the size of $\mathrm{Al}_{2} \mathrm{O}_{3}$ particles. The mixture of powders was subjected to thermal oxidation twice in air after a maximal temperature of $800{ }^{\circ} \mathrm{C}$ was reached in a stepwise manner and maintained for $120 \mathrm{~min}$. The oxidation kinetics were determined thermogravimetrically. The open porosity was evaluated by an Archimedes' principlebased method. Localization and quantification of $\mathrm{NiO}$, newly formed on the Ni particle surface and acting as a mechanical bonding agent, were explored by scanning electron microscopy with energy dispersive X-ray spectroscopy and X-ray diffractometry. Larger ceramic particles prevented merging of $\mathrm{NiO}$ layers on adjacent $\mathrm{Ni}$ particles more efficiently; therefore, the open porosity increased from $21 \%$ to $24.2 \%$ when the $\mathrm{Al}_{2} \mathrm{O}_{3}$ particle diameter was increased from 5-20 $\mu \mathrm{m}$ to $32-45 \mu \mathrm{m}$. Because both $\mathrm{Ni} / \mathrm{Al}_{2} \mathrm{O}_{3}$ composites exhibited similar flexural strength, the composite with larger $\mathrm{Al}_{2} \mathrm{O}_{3}$ particles and the higher open porosity could be a better candidate for infiltration by molten metal, or it can be directly used in a variety of filtration applications.

Keywords: $\mathrm{Ni}$ composite; $\mathrm{Al}_{2} \mathrm{O}_{3}$; moderate-temperature oxidation; $\mathrm{NiO}$; open porosity

\section{Introduction}

Ni-based composites are indispensable material in various industries given their attractive mechanical and physical properties are required for applications in high-temperature and corrosive environments [1]. Among the various composites, Ni matrix composites reinforced with $\mathrm{Al}_{2} \mathrm{O}_{3}$ particles have drawn a significant interest because $\mathrm{Ni} / \mathrm{Al}_{2} \mathrm{O}_{3}$ composites demonstrate various combinations of remarkable thermal, chemical, and mechanical properties of $\mathrm{Al}_{2} \mathrm{O}_{3}$ on the one hand and superior tensile strength and toughness of $\mathrm{Ni}$ on the other [2-4]. These properties make $\mathrm{Ni} / \mathrm{Al}_{2} \mathrm{O}_{3}$ composites exceptionally useful; $\mathrm{Ni} / \mathrm{Al}_{2} \mathrm{O}_{3}$ composites are used in advanced protective coatings against corrosion and abrasion, thus becoming an attractive alternative to chromium [5-7]. Recently, nano-composite coatings have gained remarkable interest due to a significant improvement in protection performance [8-10]. Nickel-based coatings with $\mathrm{Al}_{2} \mathrm{O}_{3}$ particles smaller than $100 \mathrm{~nm}$ in diameter have appeared and been used to increase the abrasion resistance of metal surfaces, especially in microdevices [11-14].

$\mathrm{Ni} / \mathrm{Al}_{2} \mathrm{O}_{3}$ composites are usually prepared by various traditional methods such as sol-gel processing, pressureless sintering, or hot pressing [15-21]. These approaches 
are, however, not optimal for the fabrication of open-porous products because of matrix deformation resulting in a blockage of a substantial portion of pores. The open porosity manifested by large, interconnected pores is fundamental for flow-through applications such as filtration, electrochemistry, and acoustic absorption when the required functional and structural properties are designed by the composition and the specific shape and size distribution of pores (reviewed in [22]). Open porosity is also needed to fabricate metal-matrix composites utilizing pressure-assisted or pressureless infiltration of molten metals when all pores should be filled to obtain a homogenous and dense product [23]. In addition to an appropriate open-porous structure, these preforms should display sufficient strength and resistance to a thermal shock. Considering all of these requirements, openporous $\mathrm{Ni} / \mathrm{Al}_{2} \mathrm{O}_{3}$ composites appear to be suitable candidates for the aforementioned applications. In line with this, $\mathrm{Al}_{2} \mathrm{O}_{3}$ particles make these open-porous composites a promising catalyst for the capture of carbon monoxide (CO) [24] and carbon dioxide $\left(\mathrm{CO}_{2}\right)[25,26]$. Since these greenhouse gases contribute to climate change, we require increased efforts to eliminate their accumulation in the atmosphere; open-porous $\mathrm{Ni} / \mathrm{Al}_{2} \mathrm{O}_{3}$ composites could significantly contribute to these efforts.

In general, open-porous metallic materials are conventionally fabricated using two approaches. One is a replication process when an interconnected porous network is obtained by removing (shaking or dissolution) a porous preform filled with the molten metal once solid [27]. The other is sintering of loose metal powder or fibers when poreforming agents or space fillers are used $[4,28,29]$. Although significant progress has been made in controlling pore characteristics over the years (reviewed in [30]), fabrication of open pores still remains challenging. To fully realize the application potential of openporous composites, novel fabrication technologies have to be developed and optimized.

In this study, open-porous $\mathrm{Ni} / \mathrm{Al}_{2} \mathrm{O}_{3}$ composites were prepared by a relatively simple and low-cost technology of the thermal oxidation in air when the temperature was increased stepwise up to $800{ }^{\circ} \mathrm{C}$ and maintained for $120 \mathrm{~min}$. The size effect of $\mathrm{Al}_{2} \mathrm{O}_{3}$ particles on the open porosity, internal microstructure, and flexural strength was evaluated.

\section{Materials and Methods}

\subsection{Powder Samples}

High-purity Ni powder (99.99\%, Metco 56C-NS, OC Oerlikon Corporation, Pfäffikon, Switzerland) with a particle size of $<70 \mu \mathrm{m}$ was used throughout the investigation. $\mathrm{Al}_{2} \mathrm{O}_{3}$ powder (95.50\%, Metco Amdry 6060, OC Oerlikon Corporation, Pfäffikon, Switzerland) with a particle size in the range of $5 \mu \mathrm{m}$ to $45 \mu \mathrm{m}$ was added into Ni powder samples (12.87 wt. $\% \mathrm{Al}_{2} \mathrm{O}_{3}$ corresponding to 25 vol. $\% \mathrm{Al}_{2} \mathrm{O}_{3}$ when solid density was used for conversion). The maximum volume fraction was determined experimentally, because more than 25 vol. $\% \mathrm{Al}_{2} \mathrm{O}_{3}$ resulted in a substantially weak sample cohesion after thermal oxidation. $\mathrm{Al}_{2} \mathrm{O}_{3}$ powder was sieved to gain two fractions with particle sizes of 5-20 $\mu \mathrm{m}$ and $32-45 \mu \mathrm{m}$, respectively. Analysis of the particle size distribution (the $\mathrm{D}_{50}$ parameter) was obtained for Ni powder and both $\mathrm{Al}_{2} \mathrm{O}_{3}$ fractions by laser diffraction in water using Analysette 22 NanoTec (Fritsch, Germany). The value of mean particle size $\left(\mathrm{D}_{50}\right)$ was $69.91 \mu \mathrm{m}$ for the Ni powder, $27.73 \mu \mathrm{m}$ for the $5-20 \mu \mathrm{m} \mathrm{Al}{ }_{2} \mathrm{O}_{3}$ fraction, and $36.80 \mu \mathrm{m}$ for the $32-45 \mu \mathrm{m} \mathrm{Al} \mathrm{O}_{3}$ fraction. Although the morphology of $\mathrm{Al}_{2} \mathrm{O}_{3}$ powder exhibited a blocky shape, as stated by Oerlikon Metco company, laser diffraction to evaluate the particle size was used because it has been shown that even for blocky particles the $\mathrm{D}_{50}$ parameter is sufficiently accurate [31]. The particle morphology could also explain a slightly higher value of $\mathrm{D}_{50}$ for the $5-20 \mu \mathrm{m} \mathrm{Al} \mathrm{O}_{3}$ fraction because narrow blocky-shaped particles with a length of more than $20 \mu \mathrm{m}$ also passed through a sieve with the mesh size of $20 \mu \mathrm{m}$. The $\mathrm{Ni} / \mathrm{Al}_{2} \mathrm{O}_{3}$ powder mixtures were vigorously blended in a mechanical blender, Turbula type T2F (WAB, Muttenz, Switzerland), for $30 \mathrm{~min}$. 


\subsection{The Thermal Oxidation of Powder Mixtures}

For the first oxidation cycle, $60 \mathrm{~g}$ of Ni powder or $60 \mathrm{~g}$ of $\mathrm{Ni} / \mathrm{Al}_{2} \mathrm{O}_{3}$ powder mixtures was loosely added to a conical alumina crucible (height: $50 \mathrm{~mm}$, top diameter: $24 \mathrm{~mm}$, bottom diameter: $20 \mathrm{~mm}$ ) and heated in a tubular oven Type 018LP (Elektrické pece Svoboda, Světice u Říčan, Czech Republic) in static air. The conical shape of the crucible was critical for smooth removal of the bulky oxidized sample using only gravitational force. After the maximal temperature of $800{ }^{\circ} \mathrm{C}$ was reached in a stepwise manner (Figure 1), it was held for $120 \mathrm{~min}$ to facilitate the oxidation process. The cooling was spontaneous with a rate of approximately $1{ }^{\circ} \mathrm{C} / \mathrm{min}$. Subsequently, the sample was removed from the crucible to allow oxygen diffusion across the whole surface area of the pre-oxidized sample during the second oxidation cycle with the same thermal regime, shown in Figure 1. The weight of the powder samples and the weight gain related to a newly formed $\mathrm{NiO}$ phase during the first and second oxidation cycles were determined by the semi micro balance R200D (Sartorius, Goettingen, Germany) with an accuracy of $0.1 \mathrm{mg}$.

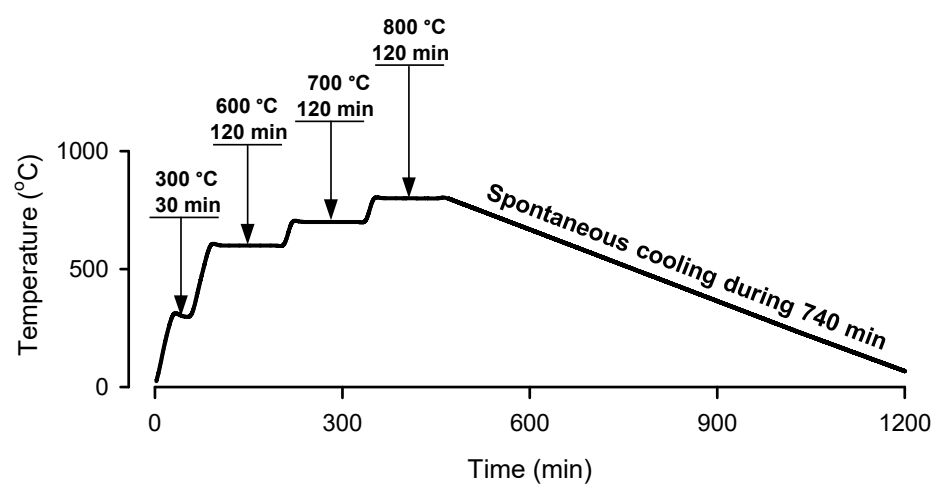

Figure 1. The time-temperature cycle of samples thermally treated in air.

\subsection{Thermogravimetric (TG) Measurement}

First, $1.2 \mathrm{~g}$ of Ni powder or $1.2 \mathrm{~g}$ of Ni/ $\mathrm{Al}_{2} \mathrm{O}_{3}$ powder mixtures, loosely filled into a smaller cylindrical alumina crucible (height: $14 \mathrm{~mm}$, diameter: $6 \mathrm{~mm}$ ) of a TG apparatus (Linseis Thermal Analyzer L75/L81/2000, Selb, Germany), was subjected into the first oxidation cycle in air using the same thermal regime (Figure 1) as was utilized for the $60 \mathrm{~g}$ samples. Keeping the sample in the TG crucible, the second oxidation cycle was run. The sample weight gain $(\Delta \mathrm{m})$ was measured as the difference between post-treatment weight $(\mathrm{m})$ and initial weight $\left(\mathrm{m}_{0}\right)$. In addition to the maximal weight gain $\left(\Delta \mathrm{m}_{\max }\right)$ reached after each thermal treatment, the oxidation behavior of the samples was monitored in detail. Because the weight gain of all samples depended only on the oxidation of $\mathrm{Ni}$ particles (not $\mathrm{Al}_{2} \mathrm{O}_{3}$ particles), the weight gain of $\mathrm{Ni} / \mathrm{Al}_{2} \mathrm{O}_{3}$ samples was related to the initial $\mathrm{Ni}$ content $\left(\mathrm{m}_{0, \mathrm{Ni}}\right)$.

\subsection{Measurement of the Open Porosity}

The open porosity of the $60 \mathrm{~g} \mathrm{Ni}$ sample and $60 \mathrm{~g} \mathrm{Ni} / \mathrm{Al}_{2} \mathrm{O}_{3}$ sample after each oxidation cycle was assessed by the Archimedes' principle-based method. Although it is a simple method, it can generate reliable quantitative information on the samples' open porosity over a wide range of pore sizes. The sample was situated in a container and mounted above the water level. When a vacuum was achieved in the closed container, the sample was immersed into distilled water. The open porosity was deduced from the difference between sample weights before and after water saturated the pores. For this purpose, the semi-micro balance R200D (Sartorius, Goettingen, Germany) with an accuracy of $0.1 \mathrm{mg}$ was utilized. 


\subsection{Analyses of the Microstructure and Chemical Composition}

The microstructures of the $60 \mathrm{~g}$ Ni sample and $60 \mathrm{~g} \mathrm{Ni} / \mathrm{Al}_{2} \mathrm{O}_{3}$ sample were determined by scanning electron microscopy (SEM) utilizing JEOL JSM 6610 (Jeol, Tokyo Japan). Specifically, the top, middle, and bottom of the bulky samples were analyzed to evaluate volume heterogeneity. The samples were found to be brittle after the first oxidation cycle; the particles fell out during grinding and polishing. Therefore, detailed microstructure analysis was performed only after the second oxidation cycle (Figure 2). For illustration purpose, SEM images after the first oxidation cycle are shown because the top region of samples was sturdy enough for metallographic preparation. A newly formed $\mathrm{NiO}$ phase was identified and localized on the surface of the Ni particles by combining SEM with energy dispersive X-ray spectroscopy (EDS, OI X-max 50 mm, Oxford Instruments, Tubney Woods, Abingdon, UK). NiO thickness was determined from SEM pictures when only $\mathrm{Ni}$ particles with a diameter around $\mathrm{D}_{50}$ were selected for measurement. On each Ni particle, one measurement of $\mathrm{NiO}$ thickness was performed. In total, more than $30 \mathrm{Ni}$ particles were included in one dataset, characterizing the top, middle, and bottom of the $60 \mathrm{~g}$ sample.

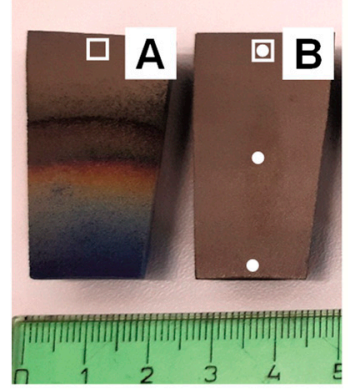

(a)

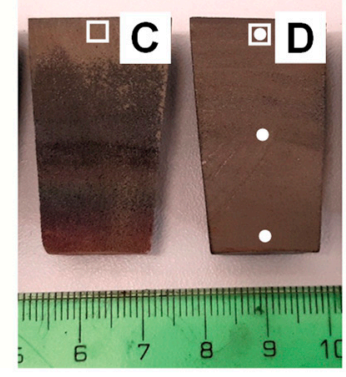

(b)

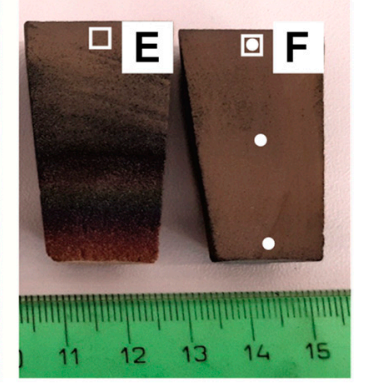

(c)

Figure 2. Macrostructure of oxidized samples: (a) $\mathrm{Ni}$; (b) $\mathrm{Ni}$ with $\mathrm{Al}_{2} \mathrm{O}_{3}$ particles with a diameter of 5-20 $\mu \mathrm{m}$; (c) Ni with $\mathrm{Al}_{2} \mathrm{O}_{3}$ particles with a diameter of 32-45 $\mu \mathrm{m}$. A, C, E after the first oxidation cycle; B, D, F after the second oxidation cycle. The open white squares indicate regions from which SEM images were taken. The white dots represent regions where SEM, EDS, and XRD analyses were performed.

The qualitative and semiquantitative phase compositions of samples in three different regions (top, middle, bottom) were studied by SEM-EDS and more specifically by $\mathrm{X}$-ray diffraction (XRD) using Bruker AXS D8 (Bruker AXS GMBH, Karlsruhe, Germany) Advance diffractometer with $\mathrm{Cu} \mathrm{K} \alpha$ radiation in parallel beam configuration with a Goebel mirror in the incident beam and a 0.23 deg Soller slit and LiF monochromator in the diffracted beam path. The measurements were performed under a constant incidence angle of 10 degrees with a collection time of $8 \mathrm{~s}$ per step in steps of $0.05 \mathrm{deg}$. Semiquantitative phase analysis was carried out using a TOPAS 3.0 (Bruker AXS, Bruker AXS GMBH, Karlsruhe, Germany) in the Rietveld-like mode; phase content determination accuracy was 1 mass $\%$. To avoid misinterpretation when comparing $\mathrm{Ni} / \mathrm{Al}_{2} \mathrm{O}_{3}$ samples to the $\mathrm{Ni}$ sample, the content of $\mathrm{NiO}$ in $\mathrm{Ni} / \mathrm{Al}_{2} \mathrm{O}_{3}$ samples was expressed as a portion (wt.\%) from the post-treatment $\mathrm{Ni} / \mathrm{NiO}$ content rather than from the $\mathrm{Ni} / \mathrm{NiO} / \mathrm{Al}_{2} \mathrm{O}_{3}$ content. The results are reported as the average \pm SEM. Statistical comparisons of differences were made by the one- or two-way ANOVA with Tukey's post hoc test. Differences were regarded to be statistically significant at $p<0.05$.

\subsection{Flexural Strength Testing}

The strength of samples, which were oxidized twice, was assessed by a three-point bending test $[32,33]$. Flexural strength testing was carried out on Zwick/Roell Z100 
materials testing machine (ZwickRoell, Ulm, Germany) at room temperature with a loading rate of $0.2 \mathrm{~mm} / \mathrm{min}$. The flexural strength $\left(\sigma_{f l s}\right)$ was calculated from the following equation:

$$
\sigma_{f l s}=\frac{\frac{F L}{4}}{\frac{h^{2}}{12}\left(\frac{b_{1}^{2}+4 b_{1} b_{2}+b_{2}^{2}}{2 b_{1}+b_{2}}\right)}
$$

where $F$ is the critical load for the fracture, $L$ is the span length of $50 \mathrm{~mm}, b_{1}$ is the base width, $b_{2}$ is the top width, and $h$ is the height of the specimen with a trapezoidal prism shape (Figure 3). Here, $b_{1}$ and $b_{2}$ were $10 \mathrm{~mm}$ and $5.5 \mathrm{~mm}$, respectively, and $\mathrm{h}$ was $6 \mathrm{~mm}$. The length of the tested specimen was $85 \mathrm{~mm}$.

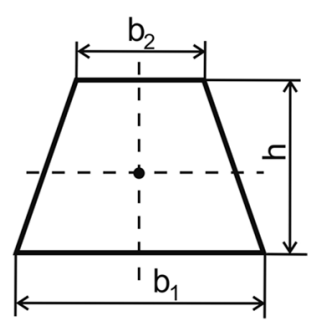

Figure 3. Cross-section of the sample for flexural strength testing.

\section{Results and Discussion}

\subsection{TG Measurement}

In 2017, we reported that $\mathrm{Al}_{2} \mathrm{O}_{3}$ particles increased the open porosity of the $\mathrm{Ni} / \mathrm{Al}_{2} \mathrm{O}_{3}$ composite $\left(\mathrm{Ni}+12.87\right.$ wt. $\% \mathrm{Al}_{2} \mathrm{O}_{3}$ - corresponding to $25 \mathrm{vol} . \% \mathrm{Al}_{2} \mathrm{O}_{3}$ ) fabricated by two cycles of thermal oxidation in air and at temperatures $\leq 800{ }^{\circ} \mathrm{C}$ [34]. We found that ceramic particles impeded the formation of a robust $\mathrm{NiO}$ network as a result of Ni oxidation. In this case, only $\mathrm{Al}_{2} \mathrm{O}_{3}$ particles of 20-32 $\mu \mathrm{m}$ diameter were tested and the powder mixture was placed in a smaller crucible with a $16 \mathrm{~mm}$ diameter. Here, as a proof of concept, the role of the $\mathrm{Al}_{2} \mathrm{O}_{3}$ particle size in porosity formation was studied in more details. Specifically, two $\mathrm{Al}_{2} \mathrm{O}_{3}$ fractions with particle diameters of 5-20 $\mu \mathrm{m}$ and 32-45 $\mu \mathrm{m}$, respectively, were tested. First, TG measurement was used to assess the sample behavior after the first and the second oxidation cycles (Figure 4). From the qualitative point of view, all three samples exhibited a similar weight-gain profile during the first oxidation cycle (Figure 4a). Using the thermal regime displayed in Figure 1, the weight of all three tested samples increased almost linearly with time when the temperature was elevated stepwise up to $800{ }^{\circ} \mathrm{C}$. Of note, this increase was not terminated immediately when heating was stopped and spontaneous cooling began. It continued during the next $350 \mathrm{~min}$ due to heat consumption accumulated during the oxidative exothermic reaction. For the Ni sample, the weight gain after the first oxidation cycle $\left(11.57 \%\right.$ ) was slightly greater than that for both $\mathrm{Ni} / \mathrm{Al}_{2} \mathrm{O}_{3}$ samples $(10.18 \%$ and $10.47 \%$, respectively) because of the steeper increase during the heating and cooling phases (Figure $4 \mathrm{a}$ ). Almost the same behavior with the similar final weight gain was exhibited by both $\mathrm{Ni} / \mathrm{Al}_{2} \mathrm{O}_{3}$ samples (Figure $4 \mathrm{~b}$ ). The second oxidation cycle running under the same conditions (the sample kept in a crucible) had a much smaller effect on all three tested samples (Figure 4a). However, there was a larger difference between samples containing $\mathrm{Al}_{2} \mathrm{O}_{3}$ particles of various sizes in this case. The larger the particle size, the larger was the weight gain achieved (3.7\% for smaller particles vs. $4.56 \%$ for larger particles). Notably, the Ni sample exhibited the lowest weight gain. The presence of $\mathrm{Al}_{2} \mathrm{O}_{3}$ particles substantially increased the steepness of the TG curve at $800{ }^{\circ} \mathrm{C}$, pointing to acceleration in $\mathrm{Ni}$ oxidation. Again, an ongoing increase in the weight gain during the cooling phase for all three samples lasting for 350 min was observed (Figure 4a). When the total weight gain after two subsequent oxidation cycles was calculated, only negligible differences between samples were revealed. Moreover, it is evident that the $\mathrm{Al}_{2} \mathrm{O}_{3}$ particle 
size did not play any significant role in the total weight gain, albeit a slightly stronger impact of the larger particles could be seen (Figure $4 b$ ).

1st oxidation

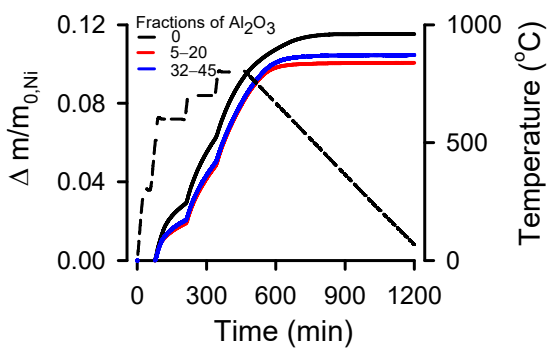

2nd oxidation

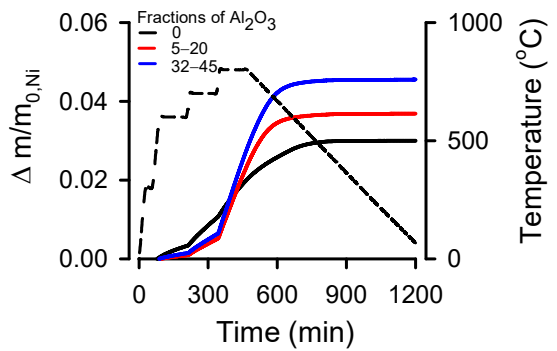

(a)
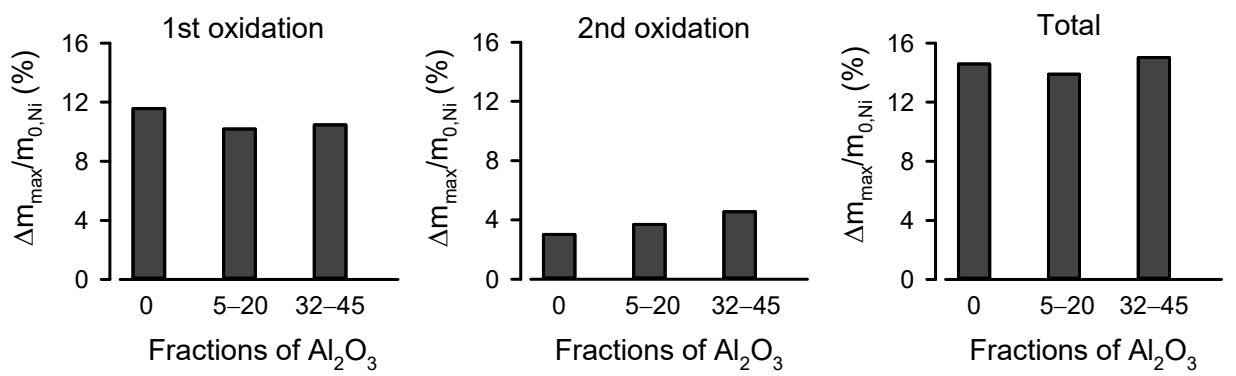

(b)

Figure 4. Relative weight gain of oxidized samples. (a) $\mathrm{Ni}$ (black line), $\mathrm{Ni}$ with $\mathrm{Al}_{2} \mathrm{O}_{3}$ particles with a diameter of 5-20 $\mu \mathrm{m}$ (red line), and $\mathrm{Ni}$ with $\mathrm{Al}_{2} \mathrm{O}_{3}$ particles with a diameter of $32-45 \mu \mathrm{m}$ (blue line) during heating in air (dashed line); (b) The final relative weight gain after the first and second cycles and a summary after two oxidation cycles.

\subsection{Impact of the Sample Weight and Dimensions}

It has been evidenced in our previous work [34], and in agreement with others [35,36], that the weight gain was caused solely by the formation of $\mathrm{NiO}$ layers on the surface of $\mathrm{Ni}$ particles as a result of thermal oxidation. Moreover, it has been reported that the $\mathrm{NiO}$ growth gave rise to the sample open porosity [34]. In an attempt to understand the role of $\mathrm{Al}_{2} \mathrm{O}_{3}$ particle size in pore formation and distribution, the weight gain was associated with the sample porosity determined by the Archimedes' principal-based method. For this purpose, we used $60 \mathrm{~g}$ samples instead of the $1.2 \mathrm{~g}$ samples usually used for TG analysis. Samples were heated in a laboratory oven utilizing the same thermal regime (Figure 1) as in the TG apparatus. The final weight gain was assessed by a precise laboratory balance. First, we examined whether such an increase in the sample weight and inevitably dimension could influence the demonstrated weight gain of the $1.2 \mathrm{~g}$ samples. Figure 5 summarizes yielded results. Interestingly, after the first oxidation cycle, the weight gain was considerably smaller for the $60 \mathrm{~g}$ samples regardless of the $\mathrm{Al}_{2} \mathrm{O}_{3}$ particles present (Figure 5). This behavior could be explained by a limited oxygen diffusion towards the bottom of the $60 \mathrm{~g}$ samples with a bigger volume. However, the $60 \mathrm{~g}$ samples underwent much larger changes after the second oxidation cycle (Figure 5). Obviously, this behavior was a reasonable consequence of releasing the sample from a crucible before the second oxidation. Despite the aforementioned differences, the total weight gain after two oxidation cycles was comparable between the $60 \mathrm{~g}$ and $1.2 \mathrm{~g}$ samples (Figure 5), pointing to a strong compensatory effect of oxidation, which ran out of a crucible in the case of the bulky sample. 


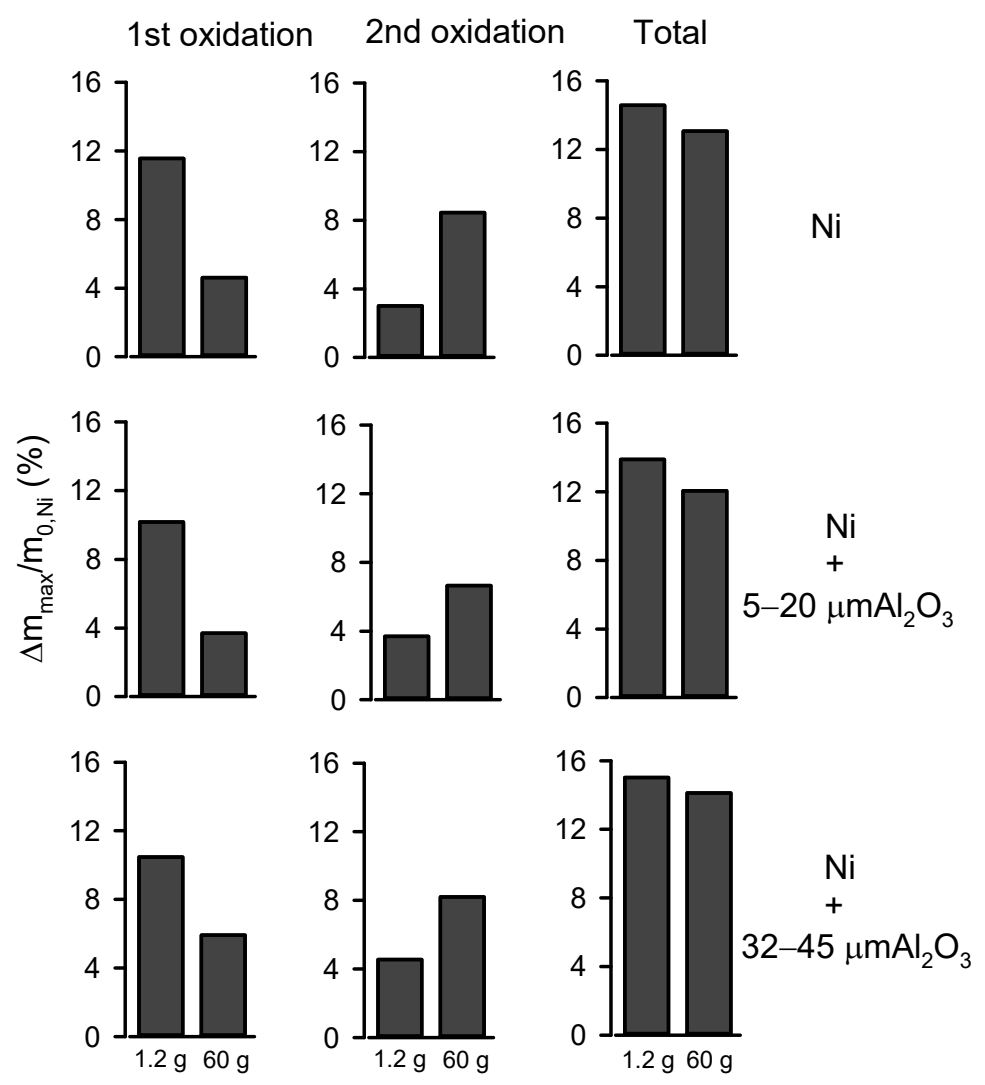

Figure 5. Effects of sample weight on maximum weight gain of samples after the first and second oxidation cycles and a summary after two oxidation cycles.

\subsection{Correlation between Weight Gain and Open Porosity}

It was of our primary interest to validate our hypothesis about the substantial role of $\mathrm{Al}_{2} \mathrm{O}_{3}$ particle size in distributing open pores in $\mathrm{Ni} / \mathrm{Al}_{2} \mathrm{O}_{3}$ composites. As displayed in Figure $6 \mathrm{~b}$, the sample with larger $\mathrm{Al}_{2} \mathrm{O}_{3}$ particles $(32-45 \mu \mathrm{m})$ exhibited the highest open porosity after the first and second oxidation cycles (36.2\% and $24.2 \%$, respectively). This behavior was accompanied with either a similar or slightly larger increase in the sample weight gain when compared to that of the Ni sample with the lowest open porosity ( $14.7 \%$ after the second oxidation). Comparing oxidation treatments, the open porosity was substantially decreased when all three samples were repeatedly oxidized (Figure 6a). Our results are consistent with the work of $\mathrm{Zhao}$ et al. [33] who studied $\mathrm{Al}_{2} \mathrm{O}_{3}$ as a porosity agent in $\mathrm{Cu}-\mathrm{Sn}-\mathrm{Ti} / \mathrm{Al}_{2} \mathrm{O}_{3}$ composites.

We assumed that some sort of internal $\mathrm{NiO}$ network was built by connecting $\mathrm{NiO}$ layers formed on the $\mathrm{Ni}$ surface. With growing a more robust $\mathrm{NiO}$, a decrease in the level of open porosity could be expected, albeit the role of a porosity agent, in our case $\mathrm{Al}_{2} \mathrm{O}_{3}$ particles, has to be also counted. To verify this conclusion at the structural level, the SEM analysis was conducted after each oxidation cycle. Figure 7 shows representative SEM images from the top region of samples. It is evident that much thicker $\mathrm{NiO}$ layers were formed in the Ni sample, which became highly interconnected, particularly after the second oxidation (Figure 7, top panels). The presence of $\mathrm{Al}_{2} \mathrm{O}_{3}$ particles substantially inhibited $\mathrm{NiO}$ networking (Figure 7, middle and bottom panels). The kinetics of the $\mathrm{NiO}$ growth has been extensively studied in a wide temperature range [37-40] because $\mathrm{Ni}$ is of a prime interest, displaying one of the highest oxidation rate constants among the corrosionresistant metals [40]. Jeangros et al. [41] demonstrated that at $300{ }^{\circ} \mathrm{C}$, voids of $5-10 \mathrm{~nm}$ width began to be formed at the $\mathrm{Ni} / \mathrm{NiO}$ interface as a consequence of the Kirkendall effect when $\mathrm{Ni}^{2+}$ diffusion across the $\mathrm{NiO}$ layer was faster than the opposite diffusion of $\mathrm{O}^{2-}$ [35]. 
At this stage, new $\mathrm{NiO}$ regions began to form outwards at the $\mathrm{NiO} / \mathrm{O}_{2}$ interface and made the oxide growth rate faster. In fact, we demonstrated that the TG curves obtained for $\mathrm{Ni}$ and $\mathrm{Ni} / \mathrm{Al}_{2} \mathrm{O}_{3}$ samples had a slower weight gain up to $300{ }^{\circ} \mathrm{C}$ during the first oxidation cycle (Figure 4a). Around $300{ }^{\circ} \mathrm{C}$, oxidation kinetics were accelerated for all three samples. In addition, Atkinson et al. [35] and Jeangros et al. [41] evidenced cracking of the $\mathrm{NiO}$ layer that resulted in formation of permeation pathways for oxygen to a fresh $\mathrm{Ni}$ surface. In such a scenario, a new $\mathrm{NiO}$ phase will also be formed directly on the surface of the $\mathrm{Ni}$ particles. In SEM images, some voids under the $\mathrm{NiO}$ layers after the first oxidation cycle were detected (Figure 7). However, they did not accumulate. Therefore, strong $\mathrm{Ni} / \mathrm{NiO}$ contacts were maintained in all samples. Even the second oxidation treatment did not lead to the nucleation of multiple voids (Figure 7); thus, the NiO layer stayed in contact with the surface of a not fully oxidized Ni particle. Because we did not measure the closed porosity, the presence of the Kirkendall effect remains to be elucidated.
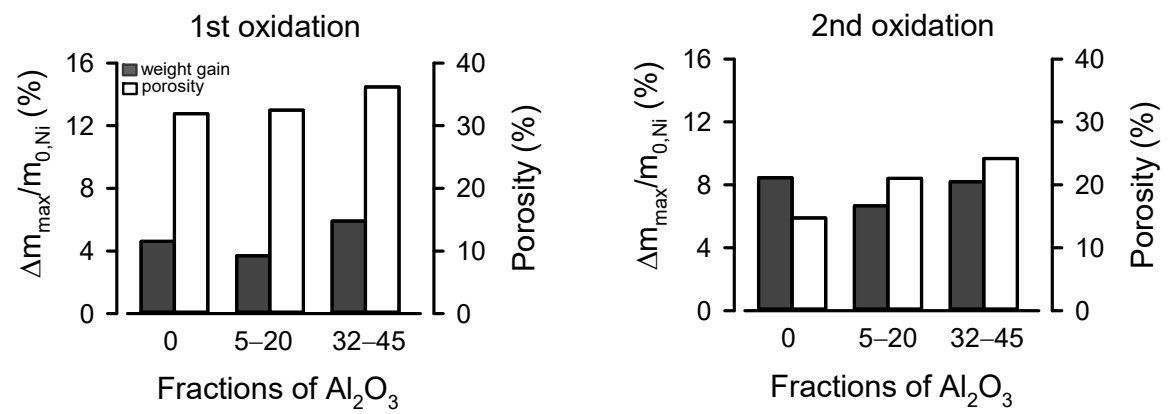

(a)

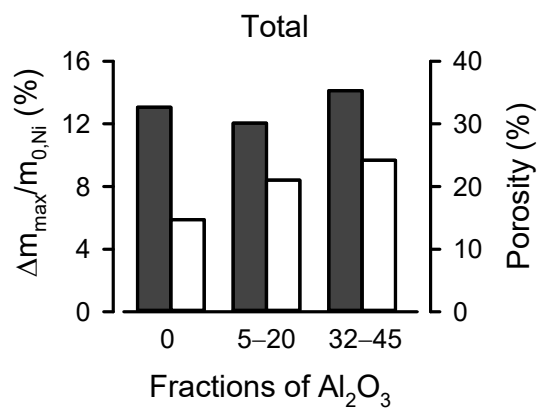

(b)

Figure 6. Comparison of the final relative weight gain (black column) of samples and the open porosity (white column): (a) after the first and second oxidation cycles; (b) summary after two oxidation cycles.

Although the 20-32 $\mu \mathrm{m} \mathrm{Al}_{2} \mathrm{O}_{3}$ fraction was examined in previous work [34], these data cannot be simply combined with those demonstrated in the present work. The main reason likely lies with the different volumes of samples, which could affect the open porosity. The $\mathrm{Ni} / \mathrm{Al}_{2} \mathrm{O}_{3}$ samples investigated in our previous work [34] were smaller by $36 \%$ than those tested here. In line with this, we evidenced that the weight gain of the $1.2 \mathrm{~g}$ samples was larger than that of the $60 \mathrm{~g}$ samples (Figure 5), which directly points to the larger amount of $\mathrm{NiO}$. This in turn facilitates $\mathrm{NiO}$ interconnecting, and lower open porosity could be expected. Indeed, it was found that the $\mathrm{Ni} / \mathrm{Al}_{2} \mathrm{O}_{3}$ sample, although containing $\mathrm{Al}_{2} \mathrm{O}_{3}$ particles of moderate size $(20-32 \mu \mathrm{m})$, exhibited the lowest open porosity (28.3\% after the first oxidation; $19.2 \%$ after the second oxidation) in the present study. 


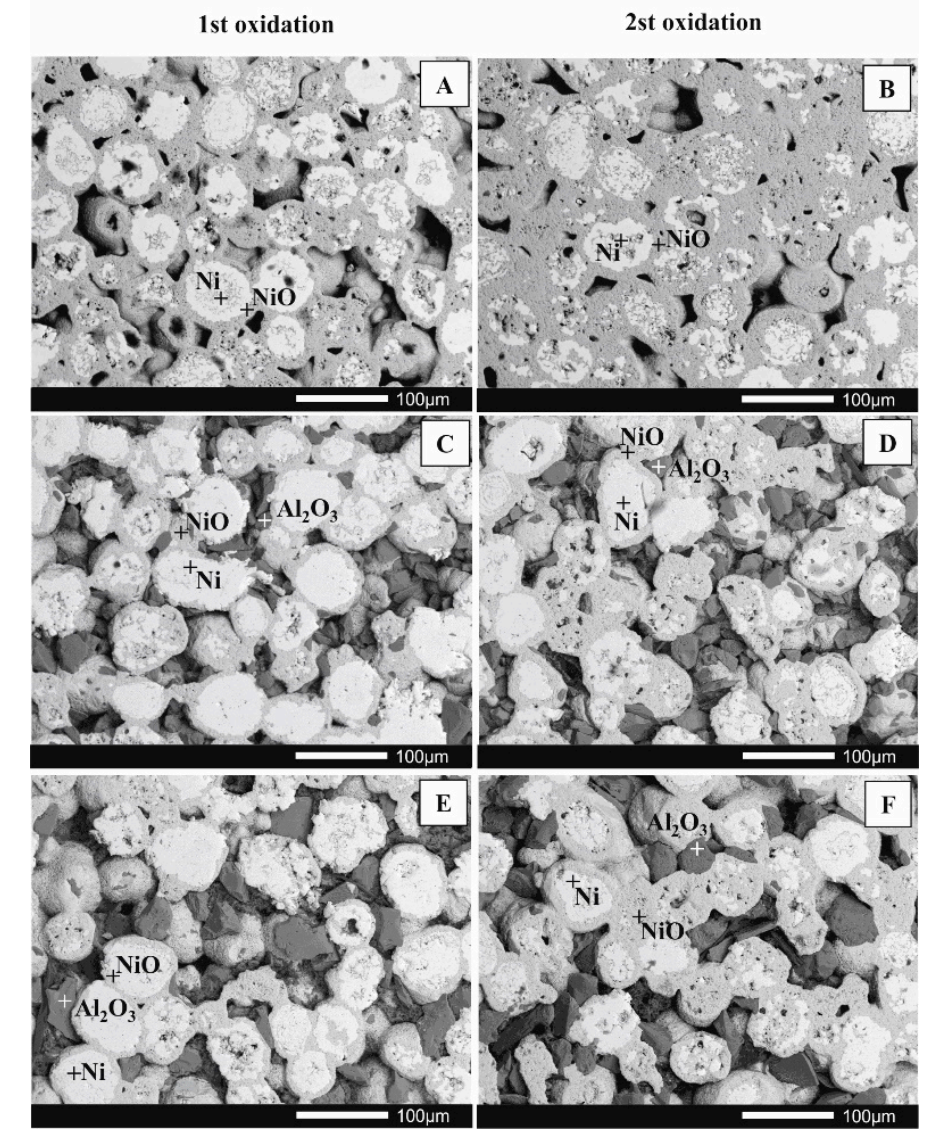

Figure 7. SEM images from the top region of the oxidized samples: $\mathrm{Ni}(\mathbf{A}, \mathbf{B})$, $\mathrm{Ni}$ with $\mathrm{Al}_{2} \mathrm{O}_{3}$ particles with a diameter of 5-20 $\mu \mathrm{m}(\mathbf{C}, \mathbf{D})$, and a sample of $\mathrm{Ni}$ with $\mathrm{Al}_{2} \mathrm{O}_{3}$ particles with a diameter of 32-45 $\mu \mathrm{m}(\mathbf{E}, \mathbf{F})$. A, C, E after the first oxidation cycle; B, D, F after the second oxidation cycle.

\subsection{NiO Amount and NiO Thickness Related to Open Porosity}

To obtain a quantitative view, the $\mathrm{NiO}$ amount and thickness of $\mathrm{NiO}$ layers was determined in three regions (top, middle, and bottom) of each twice-oxidized sample. Typical XRD patterns in the middle position of $\mathrm{Ni}$ and $\mathrm{Ni} / \mathrm{Al}_{2} \mathrm{O}_{3}$ samples are presented in Figure 8a. They include intense narrow peaks corresponding to $\mathrm{Ni}$ and $\mathrm{NiO}$ phases and weak peaks corresponding to $\mathrm{Al}_{2} \mathrm{O}_{3}$. Figure $8 \mathrm{~b}$ summarizes XRD data. Analysis of XRD patterns revealed that $\mathrm{Al}_{2} \mathrm{O}_{3}$ particles substantially reduced differences in $\mathrm{NiO}$ amount between the individual examined regions, reflecting the higher open porosity of $\mathrm{Ni} / \mathrm{Al}_{2} \mathrm{O}_{3}$ samples in comparison to that of the $\mathrm{Ni}$ sample (Figure 6). The larger $\mathrm{Al}_{2} \mathrm{O}_{3}$ particles completely abolished differences between tested regions, pointing to an increased chemical homogeneity in a sample volume. In addition, the averaged $\mathrm{NiO}$ amount over the sample volume was the largest when $\mathrm{Al}_{2} \mathrm{O}_{3}$ particles of $32-45 \mu \mathrm{m}$ diameter were added; although, the increase did not reach statistical significance (Figure 8d). To assess an error introduced by the porosity of the samples, XRD data were validated by calculating the $\mathrm{NiO}$ amount from EDS analysis. Similarly, the highest heterogeneity regarding the $\mathrm{NiO}$ amount was found for the Ni sample (Figure 8c). Both $\mathrm{Ni} / \mathrm{Al}_{2} \mathrm{O}_{3}$ samples displayed much smaller differences among top, middle, and bottom positions. Comparing averaged XRD and EDS data, a quantitative agreement highlighting a role of the $\mathrm{Al}_{2} \mathrm{O}_{3}$ particle size in $\mathrm{NiO}$ formation was found, presumably by regulating oxygen delivery (Figure 8d). 


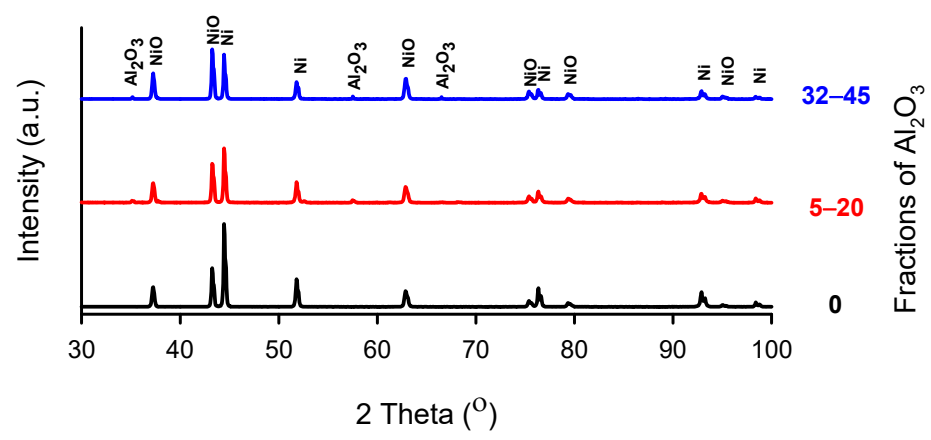

(a)

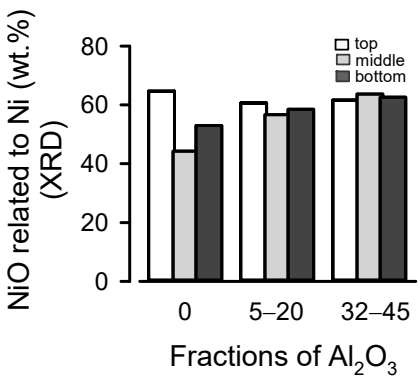

(b)

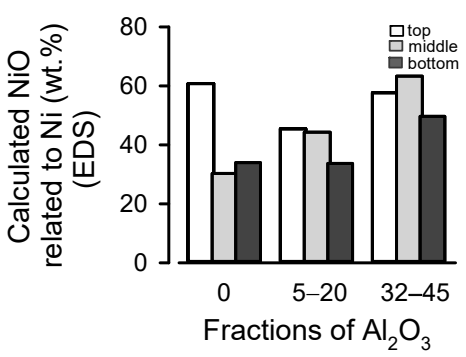

(c)

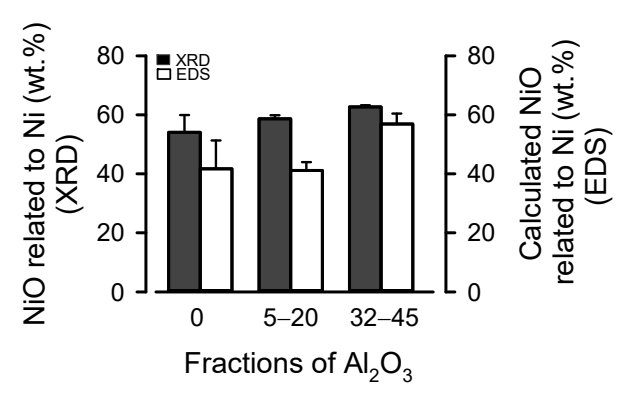

(d)

Figure 8. Analysis of $\mathrm{NiO}$ after two oxidation cycles. (a) X-ray diffraction pattern taken from the middle part of samples; $\mathrm{NiO}$ amount derived from (b) XRD and (c) EDS performed in three different regions (top, middle, and bottom); (d) Correlation between averaged XRD and EDS values for NiO.

The experimentally determined $\mathrm{NiO}$ amount was then related to the sample porosity. As shown in Figure 9a, although, $\mathrm{Ni} / \mathrm{Al}_{2} \mathrm{O}_{3}$ samples displayed increased open porosity when compared to that of the Ni sample, a statistically similar amount of $\mathrm{NiO}$ was grown in all three samples. This phenomenon could be explained by the presence of $\mathrm{Al}_{2} \mathrm{O}_{3}$ particles, which impeded abrupt synthesis of $\mathrm{NiO}$ in the top region-the main pathway for oxygen delivery during the first oxidation cycle (Figure $8 b-d$ ) - and thus pore clogging by the interconnection of $\mathrm{NiO}$ layers was avoided (Figure 7, left panels). SEM images shown in Figure 7 demonstrate that the presence of $\mathrm{Al}_{2} \mathrm{O}_{3}$ particles modified the thickness of $\mathrm{NiO}$ layers. Therefore, this parameter has been quantitatively estimated in three regions (top, middle, and bottom) of each twice-oxidized sample (Figure 9c). The presence of larger $\mathrm{Al}_{2} \mathrm{O}_{3}$ particles resulted in a volume homogeneity in respect to the $\mathrm{NiO}$ amount and $\mathrm{NiO}$ thickness. In support of this, the averaged values of these two parameters over the sample volume followed a similar trend and qualitatively correlated to each other (Figure 9b). Although data variability was not low enough to reach statistical significance for both parameters, there is a detectable increasing trend for larger $\mathrm{Al}_{2} \mathrm{O}_{3}$ particles. Their presence resulted in the growth of slightly more robust $\mathrm{NiO}$ layers while sample porosity was the highest from all tested samples (Figure 9d). These results show that larger $\mathrm{Al}_{2} \mathrm{O}_{3}$ particles occupying bigger volumes are more effective in keeping oxidized Ni particles away from 
each other to prevent their interconnection by, albeit the more robust, $\mathrm{NiO}$ layers. Because $\mathrm{NiO}$ thickness determined for tens of $\mathrm{Ni}$ particles located in the tested sample region was very similar (Figure 9c), it seems reasonable to conclude that the presence of $\mathrm{Al}_{2} \mathrm{O}_{3}$ particles did not cause any local heterogeneity to influence $\mathrm{NiO}$ growing on $\mathrm{Ni}$ particles of the same diameter.

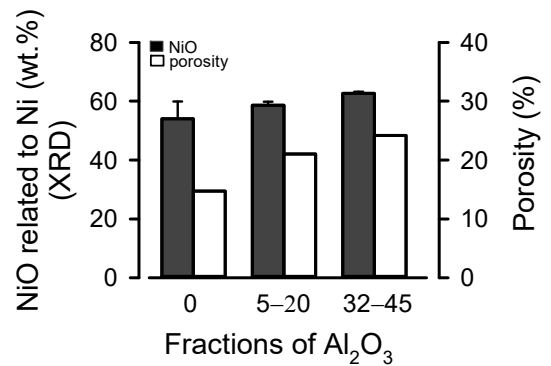

(a)

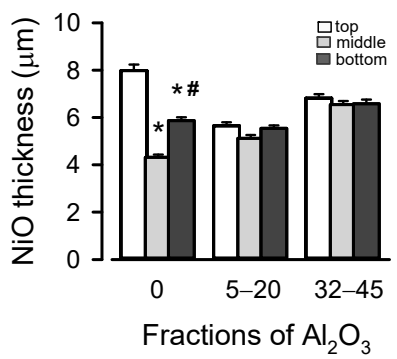

(c)

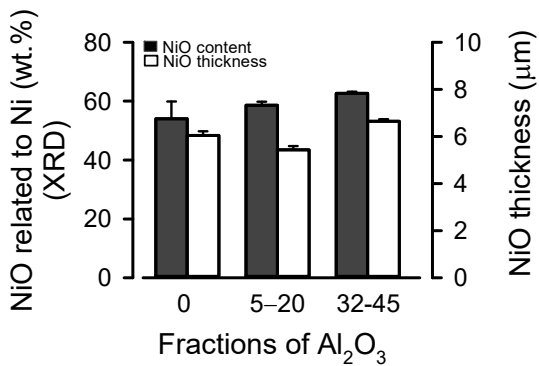

(b)

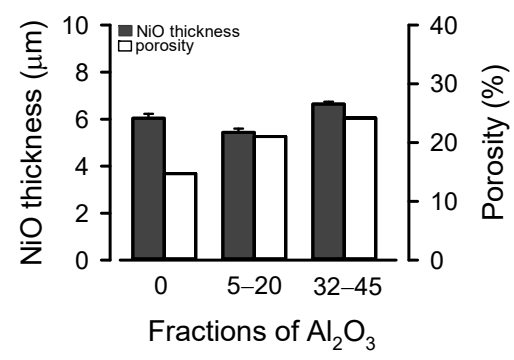

(d)

Figure 9. Correlation between $\mathrm{NiO}$ amount derived from $\mathrm{XRD}$ analysis and the open porosity (a) and $\mathrm{NiO}$ thickness (b); (c) NiO thickness measured in three distinct regions of $\mathrm{Ni}$ and $\mathrm{Ni} / \mathrm{Al}_{2} \mathrm{O}_{3}$ samples; (d) Correlation between $\mathrm{NiO}$ thickness and open porosity. $\mathrm{NiO}$ amount in $(\mathbf{a}, \mathbf{b})$ is related to the $\mathrm{Ni}$ content. * Significant versus the top position, significant \# versus the middle position.

\subsection{Flexural Strength}

It is well known that mechanical properties substantially vary with the level of porosity. The relationship between porosity and the flexural strength of numerous materials has been widely studied at both experimental and theoretical levels [42-45]. Understanding this relationship is of great importance because it is necessary for optimizing the application of porous metallic materials when, for example, high open porosity with a maximal possible strength is often needed. Therefore, we tested the flexural strength of $\mathrm{Ni}$ and $\mathrm{Ni} / \mathrm{Al}_{2} \mathrm{O}_{3}$ samples utilizing the 3-point bending test. Figure 10a shows representative load-displacement curves recorded for all three tested samples. The load increased in direct proportion to the deflection up to cracking, and differences between flexural performance were found only in the maximal load. The $\mathrm{Ni}$ sample exhibited a superior flexural response cracking at $532.81 \mathrm{~N}$ load. In contrast, the failure load for $\mathrm{Ni} / \mathrm{Al}_{2} \mathrm{O}_{3}$ samples was substantially lower $\left(94.72 \mathrm{~N}\right.$ and $140.6 \mathrm{~N}$ for $\mathrm{Al}_{2} \mathrm{O}_{3}$ particles of $5-20 \mu \mathrm{m}$ and 32-45 $\mu \mathrm{m}$, respectively). Figure $10 \mathrm{~b}$ summarizes data for the flexural strength calculated using Equation (1) and correlates them to open porosity. Expectedly, the highest flexural strength of the Ni sample $(141.95 \pm 2.81 \mathrm{MPa})$ corresponds to the lowest open porosity while more porous $\mathrm{Ni} / \mathrm{Al}_{2} \mathrm{O}_{3}$ samples demonstrated almost fivefold lower flexural strength $\left(27.93 \pm 0.25 \mathrm{MPa}\right.$ and $29.77 \pm 1.35 \mathrm{MPa}$ for $\mathrm{Al}_{2} \mathrm{O}_{3}$ particles of $5-20 \mu \mathrm{m}$ and 32-45 $\mu \mathrm{m}$, respectively). Although the size of $\mathrm{Al}_{2} \mathrm{O}_{3}$ particles influenced the flexural performance only negligibly, it substantially modified the sample open porosity (Figure 10b). Thus, the addition of larger $\mathrm{Al}_{2} \mathrm{O}_{3}$ particles resulted in a more porous $\mathrm{Ni} / \mathrm{Al}_{2} \mathrm{O}_{3}$ composite while retaining a similar strength to that of a less porous sample with smaller ceramic particles. Because mechanical properties reflect the internal structure [43], this specific behavior of the 
sample with the bigger $\mathrm{Al}_{2} \mathrm{O}_{3}$ particles could be explained by almost absolute homogeneity in respect to $\mathrm{NiO}$ amount and $\mathrm{NiO}$ thickness (Figures $8 \mathrm{~b}$ and $9 \mathrm{c}$ ). In addition, mechanical bonding can be likely achieved by the interlocking of adjacent $\mathrm{NiO}$ layers. $\mathrm{NiO}$ layers do not grow as ideal smooth surfaces at the microstructural level; instead, there are some preferential orientations of growing oxide. This process greatly depends on the possibility of oxygen penetration into the defined area, the thickness of the already formed $\mathrm{NiO}$ layer, and locally available space. The nature of bonding, however, needs to be further explored.

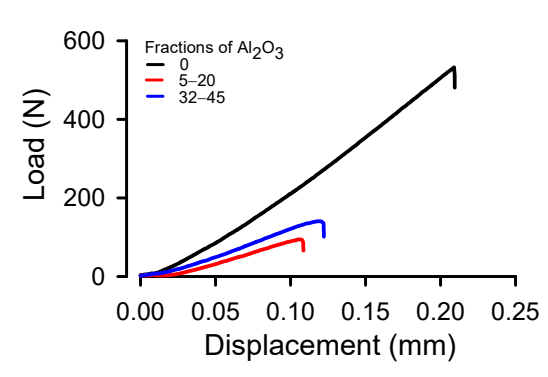

(a)

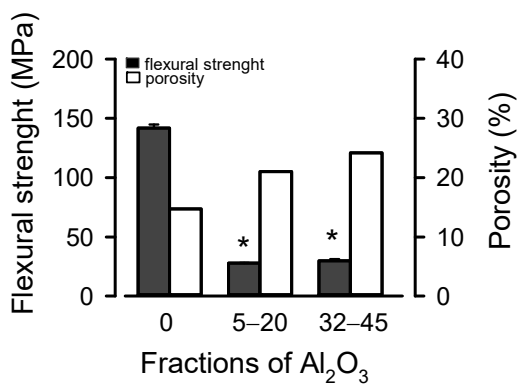

(b)

Figure 10. Flexural strength of oxidized samples. (a) Load-displacement curves recorded during the 3-point bending test for $\mathrm{Ni}$ and $\mathrm{Ni} / \mathrm{Al}_{2} \mathrm{O}_{3}$ samples; (b) Correlation between the flexural strength and open porosity. ${ }^{*}$ Significant versus the Ni sample.

\section{Conclusions}

Open-porous $\mathrm{Ni} / \mathrm{Al}_{2} \mathrm{O}_{3}$ composites were fabricated by a method of thermal oxidation in air at a moderate temperature of $800{ }^{\circ} \mathrm{C}$ for $120 \mathrm{~min}$. The open porosity was studied in relation to the size of $\mathrm{Al}_{2} \mathrm{O}_{3}$ particles and was correlated to weight gain, microstructure, and chemical composition. Our results show that by increasing the size of $\mathrm{Al}_{2} \mathrm{O}_{3}$ particles from $5-20 \mu \mathrm{m}$ to $32-45 \mu \mathrm{m}$, the open porosity of the $\mathrm{Ni} / \mathrm{Al}_{2} \mathrm{O}_{3}$ sample was increased from $21 \%$ to $24.2 \%$. Concurrently, the flexural strength was found not to be changed significantly. This specific performance is likely to be a result of volume homogeneity with respect to $\mathrm{NiO}$ amount and $\mathrm{NiO}$ thickness. While larger $\mathrm{Al}_{2} \mathrm{O}_{3}$ particles allowed for a better oxygen supply into a sample volume, stimulating $\mathrm{NiO}$ growth on the surface of $\mathrm{Ni}$ particles, they concurrently prevented massive $\mathrm{NiO}$ interconnecting, which resulted in higher open porosity. Therefore, the composite with larger $\mathrm{Al}_{2} \mathrm{O}_{3}$ particles could be an excellent candidate for infiltration by molten metal or it can be directly used in filtration applications requiring a good penetrating porosity, substantial corrosion resistance, and suitable mechanical strength. The conventional production of porous metal, ceramic, or metal-ceramic composites is technologically, energetically, and financially demanding. In most cases, a high melting point of metals, compared to that of ceramics, needs to be reached. In contrast, thermal oxidation at a moderate temperature is a simple and relatively low-cost processing route for open-porous $\mathrm{Ni} / \mathrm{Al}_{2} \mathrm{O}_{3}$ composites. In addition to being flexible and attractive, it also allows large-size components to be fabricated.

Author Contributions: Conceptualization, A.O.; methodology, A.O. and P.Š. (Pavol Štefánik); formal analysis, A.O., M.G. and P.Š. (Peter Švec); investigation, A.O., P.Š. (Peter Švec), P.Š. (Pavol Štefánik), S.K.J. and M.Š.; writing_original draft preparation, A.O. and M.G.; writing-review and editing, A.O., M.G., P.Š. (Pavol Štefánik) and K.I.; visualization, M.G.; funding acquisition, P.Š. (Peter Švec) and P.Š. (Pavol Štefánik). All authors have read and agreed to the published version of the manuscript.

Funding: This research was funded by the Slovak Scientific Grant Agency, grant number VEGA 2/0135/19; the Slovak Research and Development Agency, grant number APVV-19-0369. This research was performed during the implementation of the project Building-up Centre for advanced material application of the Slovak Academy of Sciences, ITMS project code 313021T081 supported by the Research and Innovation Operational Program funded by the ERDF. 
Data Availability Statement: The data presented in this study are available on request from the corresponding author.

Acknowledgments: The authors wish to acknowledge Oto Bajana for performing flexural strength tests.

Conflicts of Interest: The authors declare no conflict of interest. The funders had no role in the design of the study; in the collection, analyses, or interpretation of data; in the writing of the manuscript, or in the decision to publish the results.

\section{References}

1. Li, H.; Liu, R.; Chen, J.; Wang, Z.; Xiong, X. Preparation of nickel porous materials by sintering nickel oxalate and sodium chloride after blending and reduction. J. Mater. Res. Technol. 2020, 9, 3149-3157. [CrossRef]

2. Bhattacharyya, M.; Kumar, A.N.; Kapuria, S. Synthesis and characterization of $\mathrm{Al} / \mathrm{SiC}$ and $\mathrm{Ni}_{2} / \mathrm{Al}_{2} \mathrm{O}_{3}$ functionally graded ma-terials. Mater. Sci. Eng. A 2008, 487, 524-535. [CrossRef]

3. Yang, S.; Kim, H.; Lee, C.S. Investigation of shrinkage control in $\mathrm{Ni}-\mathrm{Al}_{2} \mathrm{O}_{3}$ (metal-ceramic) functionally graded materials. Ceram. Int. 2013, 39, 93-99. [CrossRef]

4. Dele-Afolabi, T.T.; Azmah Hanim, M.A.; Norkhairunnisa, M.; Sobri, S.; Calin, R.; Ismarrubie, Z.N. Significant effect of rice husk and sugarcane bagasse pore formers on the microstructure and mechanical properties of porous $\mathrm{Al}_{2} \mathrm{O}_{3} / \mathrm{Ni}$ composites. J. Alloys Compd. 2018, 743, 323-331. [CrossRef]

5. Li, Y.-b.; Yue, W.-x. Study on the $\mathrm{Al}_{2} \mathrm{O}_{3}$ contents in $\mathrm{Ni}-\mathrm{Al}_{2} \mathrm{O}_{3}$ composite coatings predicted by using BP neural network model. J. Synth. Crys. 2017, 8, 1649-1652.

6. Fan, H.; Jiang, J.; Zhao, Y.; Wang, S.; Li, Z. Improvement of microstructure and properties of $\mathrm{Ni}_{-} \mathrm{Al}_{2} \mathrm{O}_{3}$ composite coating via jet electrodeposition. J. Mod. Phys. B 2020, 34, 2050243. [CrossRef]

7. Alekseeva, E.; Shishkova, M.; Strekalovskaya, D.; Gerashchenkov, D.; Glukhov, P. Ni-Bbsed coatings for oil and gas industry fabricated by cold gas spraying. Mater. Proc. 2021, 3, 2. [CrossRef]

8. Amosov, A.P.; Titova, Y.V.; Timoshkin, I.Y.; Kuzina, A.A. Fabrication of Al-AlN nanocomposites. Key Eng. Mater. 2015, 684, 302-309. [CrossRef]

9. Aryshnskii, E.V.; Bazhin, V.Y.; Kawalla, R. Strategy of refining the structure of aluminum magnesium alloys by complex microalloying with transition elements during casting and subsequent thermomechanical processing. Non-Ferr. Met. 2019, 1, 28-32. [CrossRef]

10. Li, B.; Zhang, W.; Li, D. Synthesis and properties of a novel Ni-Co and Ni-Co/ZrO 2 composite coating by DC electrodeposi-tion. J. Alloys Compd. 2020, 821, 153258. [CrossRef]

11. Erler, F.; Jakob, C.; Romanus, H.; Spiess, L.; Wielage, B.; Lampke, T.; Steinhauser, S. Interface behaviour in nickel composite coatings with nano-particles of oxidic ceramic. Electrochim. Acta 2003, 48, 3063. [CrossRef]

12. Bhutta, M.U.; Khan, Z.A.; Garland, N. Wear performance analysis of $\mathrm{Ni}-\mathrm{Al}_{2} \mathrm{O}_{3}$ nanocomposite coatings under nonconven-tional lubrication. Materials 2019, 12, 36. [CrossRef] [PubMed]

13. Qu, G.; Wang, D.; Wang, Q.; Hua, M. Microstructure and wear resistance of $\mathrm{Ni}^{-} \mathrm{Al}_{2} \mathrm{O}_{3}$ nanocomposite coating. J. Phys. Conf. Ser. 2021, 1965, 012113. [CrossRef]

14. Na, T.; Jin, L.; Liyan, L.; Guo, J.; Xiufang, C.; Yang, W. Synthesis of Ni/nano- $\mathrm{Al}_{2} \mathrm{O}_{3}$ coatings by brush plating with magnetic fields. R. Soc. Open Sci. 2021, 8, 202089. [CrossRef]

15. Breval, E.; Deng, Z.; Chiou, S.; Pantano, C.G. Sol-gel prepared Ni-alumina composite materials. J. Mater. Sci. 1992, 27, 1464-1468. [CrossRef]

16. Tuan, W.; Lin, M.; Wu, H. Preparation of $\mathrm{Al}_{2} \mathrm{O}_{3} \mathrm{Ni}$ composites by pressureless sintering in $\mathrm{H}_{2}$. Ceram. Int. 1995, 21, 221-225. [CrossRef]

17. Chen, R.Z.; Tuan, W.H. Pressureless sintering of $\mathrm{Al}_{2} \mathrm{O}_{3} / \mathrm{Ni}$ nanocomposites. J. Eur. Ceram. Soc. 1999, 19, 463-468. [CrossRef]

18. Theerabornkul, T.; Kangwantrakool, S. Fabrication of $\mathrm{Al}_{2} \mathrm{O}_{3}-\mathrm{Ni}$ composites using ceramic nanoparticles. CMU J. Natur. Sci. 2005, $4,59-66$.

19. Isobe, T.; Daimon, K.; Sato, T.; Matsubara, T.; Hikichi, Y.; Ota, T. Spark plasma sintering technique for reaction sintering of $\mathrm{Al}_{2} \mathrm{O}_{3} / \mathrm{Ni}$ nanocomposite and its mechanical properties. Ceram. Int. 2008, 34, 213-217. [CrossRef]

20. Dawood, N.M. Erosion-corrosion behavior of $\mathrm{Al}-20 \% \mathrm{Ni}-\mathrm{Al}_{2} \mathrm{O}_{3}$ metal matrix composites by stir casting. Mater. Sci. Forum 2020, 1002, 161-174. [CrossRef]

21. Konopka, K.; Krasnowski, M.; Zygmuntowicz, J.; Cymerman, K.; Wachowski, M.; Piotrkiewicz, P. Characterization of $\mathrm{Al}_{2} \mathrm{O}_{3}$ samples and $\mathrm{NiAl}-\mathrm{Al}_{2} \mathrm{O}_{3}$ composite consolidated by pulse plasma sintering. Materials 2021, 14, 3398. [CrossRef] [PubMed]

22. Lefebvre, L.P.; Banhart, J.; Dunand, D.C. Porous metals and metallic foams: Current status and recent developments. Adv. Eng. Mater. 2008, 10, 775-787. [CrossRef]

23. Gil, R.; Jinnapat, A.; Kennedy, A.R. Pressure-assisted infiltration of molten aluminium into open cell ceramic foams: Ex-perimental observations and infiltration modelling. Compos. Part A Appl. Sci. Manuf. 2012, 43, 880-884. [CrossRef]

24. Mozaffari, N.; Solaymani, S.; Achour, A.; Kulesza, S.; Bramowicz, M.; Nezafat, N.B.; Ţălu, S.; Mozaffari, N.; Rezaee, S. New insights into $\mathrm{SnO}_{2} / \mathrm{Al}_{2} \mathrm{O}_{3}, \mathrm{Ni} / \mathrm{Al}_{2} \mathrm{O}_{3}$, and $\mathrm{SnO}_{2} / \mathrm{Ni} / \mathrm{Al}_{2} \mathrm{O}_{3}$ composite films for $\mathrm{CO}$ adsorption: Building a bridge between mi-crostructures and adsorption properties. J. Phys. Chem. C 2020, 124, 3692-3701. [CrossRef] 
25. Zhan, Y.; Wang, Y.; Gu, D.; Chen, C.; Jiang, L.; Takehira, K. Ni/ $\mathrm{Al}_{2} \mathrm{O}_{3}-\mathrm{ZrO}_{2}$ catalyst for $\mathrm{CO}_{2}$ methanation: The role of $\gamma$-(Al, $\mathrm{Zr})_{2} \mathrm{O}_{3}$ formation. Appl. Surf. Sci. 2018, 459, 74-79. [CrossRef]

26. Garbarino, G.; Kowalik, P.; Riani, P.; Antoniak-Jurak, K.; Pieta, P.; Lewalska-Graczyk, A.; Lisowski, W.; Nowakowski, R.; Busca, G.; Pieta, I.S. Improvement of $\mathrm{Ni} / \mathrm{Al}_{2} \mathrm{O}_{3}$ catalysts for low-temperature $\mathrm{CO}_{2}$ methanation by vanadium and calcium oxide addition. Ind. Eng. Chem. Res. 2021, 60, 6554-6564. [CrossRef]

27. Conde, Y.; Despois, J.-F.; Goodall, R.; Marmottant, A.; Salvo, L.; San Marchi, C.; Mortensen, A. Replication processing of highly porous materials. Adv. Eng. Mater. 2006, 8, 795-803. [CrossRef]

28. Herwig, J.; Titus, J.; Kullmann, J.; Wilde, N.; Hahn, T.; Glaser, R.; Enke, D. Hierarchically structured porous spinels via an epoxide-mediated sol-gel process accompanied by polymerization-induced phase separation. ACS Omega 2018, 3, 1201-1212. [CrossRef]

29. Weber, S.; Abel, K.L.; Zimmermann, R.T.; Huang, X.; Bremer, J.; Rihko-Struckmann, L.K.; Batey, D.; Cipiccia, S.; Titus, J.; Poppitz, D.; et al. Porosity and structure of hierarchically porous $\mathrm{Ni} / \mathrm{Al}_{2} \mathrm{O}_{3}$ catalysts for $\mathrm{CO}_{2}$ methanation. Catalysts 2020, $10,1471$. [CrossRef]

30. Kränzlin, N.; Niederberger, M. Controlled fabrication of porous metals from the nanometer to the macroscopic scale. Mater. Horiz. 2015, 2, 359. [CrossRef]

31. Naito, M.; Hayakawa, O.; Nakahira, K.; Mori, H.; Tsubaki, J. Effect of particle shape on the particle size distribution measured with commercial equipment. Powder Tech. 1998, 100, 52-60. [CrossRef]

32. Cha, S.I.; Lee, K.H.; Ryu, H.J.; Hong, S.H. Effect of size and location of spherical pores on transverse rupture strength of WC-Co cemented carbides. Mater. Sci. Eng. A 2008, 486, 404-408. [CrossRef]

33. Zhao, B.; Yu, T.; Ding, W.; Li, X. Effects of pore structure and distribution on strength of porous Cu-Sn-Ti alumina composites. Chin. J. Aeronaut. 2017, 30, 2004-2015. [CrossRef]

34. Opálek, A.; Štefánik, P.; Beronská, N.; Klimová, A.; Kúdela Jr, S.; Iždinský, K.; Nagy, Š. Ni-NiO porous preform with con-trolled porosity using $\mathrm{Al}_{2} \mathrm{O}_{3}$ powder. Mater. Sci. Forum 2017, 891, 533-536. [CrossRef]

35. Atkinson, A. Transport processes during the growth of oxide films at elevated temperature. Rev. Mod. Phys. 1985, 57, 437-469. [CrossRef]

36. Kofstad, P. High Temperature Corrosion; Elsevier Applied Science: London, UK; New York, NY, USA, 1988 ; p. 546.

37. Huntz, A.M.; Lefevre, B.; Cassino, F. Roughness and oxidation: Application to NiO growth on Ni at $800{ }^{\circ} \mathrm{C}$. Mater. Sci. Eng. A 2000, 290, 190-197. [CrossRef]

38. Haugsrud, R. On the high-temperature oxidation of nickel. Corros. Sci. 2003, 45, 211-235. [CrossRef]

39. Chevalier, S.; Desserrey, F.; Larpin, J.P. Oxygen transport during the high temperature oxidation of pure nickel. Oxid. Met. 2005, 64, 219-234. [CrossRef]

40. Unutulmazsoy, Y.; Merkle, R.; Fischer, D.; Mannhart, J.; Maier, J. The oxidation kinetics of thin nickel films between 250 and $500{ }^{\circ}$ C. Phys. Chem. Chem. Phys. 2017, 19, 9045-9052. [CrossRef]

41. Jeangros, Q.; Hansen, T.W.; Wagner, J.B.; Dunin-Borkowski, R.E.; Hebert, C.; Van Herle, J.; Hessler-Wyser, A. Oxidation mechanism of nickel particles studied in an environmental transmission electron microscope. Acta Mater. 2014, 67, 362-372. [CrossRef]

42. Wagh, A.S.; Poeppel, R.B.; Singh, J.P. Dependence of ceramic fracture properties on porosity. J. Mater. Sci. 1993, $28,3589-3593$. [CrossRef]

43. Nielsen, L.F. On strength of porous material: Simple systems and densified systems. Mater. Struct. 1998, 31, 651-661. [CrossRef]

44. Lu, G.; Lu, G.Q.; Xiao, Z.M. Mechanical properties of porous materials. J. Porous Mat. 1999, 6, 359-368. [CrossRef]

45. Kwan, Y.B.P.; Stephenson, D.J.; Aacock, J.R. The porosity dependence of flexural modulus and strength for capsule-free hot isostatically pressed porous alumina. J. Mater. Sci. 2000, 35, 1205-1211. [CrossRef] 